Canadian University Music Review

Revue de musique des universités canadiennes

\title{
The Canadian Society for Eighteenth-Century Studies / La société canadienne d'étude du dix-huitième siècle; Ninth International Congress on the Enlightenment
}

\section{Paul F. Rice}

Volume 16, numéro 2, 1996

URI : https://id.erudit.org/iderudit/1014428ar

DOI : https://doi.org/10.7202/1014428ar

Aller au sommaire du numéro

Éditeur(s)

Canadian University Music Society / Société de musique des universités canadiennes

ISSN

0710-0353 (imprimé)

2291-2436 (numérique)

Découvrir la revue

Citer ce compte rendu

Rice, P. F. (1996). Compte rendu de [The Canadian Society for Eighteenth-Century Studies / La société canadienne d'étude du dix-huitième siècle; Ninth International Congress on the Enlightenment]. Canadian

University Music Review / Revue de musique des universités canadiennes, 16(2), 116-117. https://doi.org/10.7202/1014428ar

All Rights Reserved (c Canadian University Music Society / Société de musique des universités canadiennes, 1996
Ce document est protégé par la loi sur le droit d'auteur. L'utilisation des services d'Érudit (y compris la reproduction) est assujettie à sa politique d'utilisation que vous pouvez consulter en ligne.

https://apropos.erudit.org/fr/usagers/politique-dutilisation/ 


\section{CONFERENCE REPORTS/ COMPTES RENDUS DE COLLOQUES}

\section{The Canadian Society for Eighteenth-Century Studies/La société canadienne d'étude du dix-huitième siècle; Ninth International Congress on the Enlightenment}

The twenty-first conference of CSECS/SCEDS was held on the campus of the University of Windsor from 11-15 October 1995. A campus location was a departure from previous years, when the conference was held in hotels. Conference chair, Katherine Quinsey, and her committee and team of friendly volunteers proved to be more than equal to the task of organizing the smooth running of five simultaneous sessions of papers. One could only marvel at Doctor Quinsey's energy and calm demeanour in face of the usual minor emergencies that attend such functions. Indeed, as noted below, she took part on several levels in the events of the conference.

The theme of the conference was "Freedom and Boundaries/Émancipation et frontières." One hundred and twenty-five individual papers were planned which, as is usual with this society, provided a wide range of topics relevant to the study of eighteenth-century life, literature, arts, politics, religion, and philosophy. The four plenary sessions provided insights into topics ranging from "Pierre Potier à Windsor" to aspects of slavery in the eighteenth century. Surprisingly, only two papers on music were delivered: Paul F. Rice: "John Abraham Fisher's A Comparative View of the English, French and Italian Schools: A British Musician Tours Europe," and Ursula Rempel: "Private and Public Spheres: Binary Perceptions of the Feminine Virtues in Women's Music in the Age of Accomplishments." Given the proximity of Windsor to so many other universities in central Canada, it is all-the-more regrettable that other musicians chose not to submit abstracts for this conference.

Live music did much, however, to make up for the lack of the spoken word on music at the conference. Members of the School of Music, University of Windsor, and the Windsor Symphony presented an afternoon concert of eighteenth-century music in the Assumption University Chapel which featured clarinet, oboe, trumpet, and keyboards juxtaposed with strings. The concert, a part of the School of Music's concert series, offered many delights, but it was the exceptional clarinet playing of Stephen Millen in the Carl Stamitz Quartet in E-flat Major, Op. 19, that remained long in the memory after the concert had ended. Following the banquet on 14 October, the University Chamber Singers and the Early Music Ensemble of Windsor presented a programme of seventeenth- and eighteenth-century theatre music and cantatas. The talented soprano soloist who appeared with Early Music Ensemble of Windsor in cantatas by Handel was the conference organizer, Katherine Quinsey! The ensemble 
was joined by the University Chamber singers in a performance of the celebrated "Frost Scene" from Purcell's King Arthur.

I am pleased to announce that the twenty-second meeting of the society will be hosted by the University of Victoria in October 1996. The conference theme will be "Theatre of the World/Le théâtre du monde." The formal call for papers will be made in early 1996 . The society publishes a select number of the conference papers in its journal Lumen (formerly Man and Nature/L'homme et la nature). Those wishing to join the society should contact Dr. Eleanor Ty, Department of English, Wilfrid Laurier University, Waterloo, Ontario, N2L 3C5.

Membership in CSECS automatically bestows membership in the International Society for Eighteenth-Century Studies, a society which holds a major Congress every four years. The Ninth International Congress on the Enlightenment was held at the Westfälische Wilhelms-Universität, Münster, 23-29 July 1995. Münster, one of the most charming cities in Westfalia, provided an idyllic setting for what proved to be an occasionally chaotic conference experience. Professor Werner Schneiders was entrusted with the enormous task of organizing a conference so large that four buildings were needed for the presentations of the nearly 900 speakers. Even the most careful planning could not ensure that papers and sessions began and ended on schedule, with the result that it was difficult to move from one session to another.

The performing arts were better represented at the ISECS conference than at the later CSECS conference, and three sessions were set aside for discussions of opera, musical aesthetics, and musical culture. Space does not permit a complete listing of papers; however, the Canadian representatives were Patricia Debly (Brock University), "Joseph Haydn and the Tradition of the Abduction Opera," and Paul F. Rice (Memorial University of Newfoundland), "Power, Politics and the Production of Opera: Mme de Pompadour, Mondonville and Rameau." In an evening concert (24 July), Ingrid Schmithüsen (soprano) and Trio 1790 (Harold Hoeren, fortepiano; Matthias Fisher, violin; Philipp Bosbach, cello) performed a variety of instrumental and vocal works, and included music by lesser-known composers, such as Johann Abraham Peter Schultz, Justin August Just, Franziska Lebrun, and Christian Gottlob Neefe. The concert was presented in the lovingly-restored Erbdrostenhof, a building designed by the Münster architect, J.C. Schlaun (1695-1773), and regarded by many as being his masterpiece. Münster celebrated the tri-centennial of Schlaun's birth in great style, with a variety displays featuring his work throughout the city.

The next International Congress will take place in Dublin in 1999. Once again, it is expected that a large number of delegates will attend. Hopefully, there will be a larger representation from Canadian musicians. The society publishes abbreviated versions of all papers presented at its congresses in the journal of the Voltaire Foundation. Thus, there are two outlets for Canadian musicians with an interest in eighteenth-century music to present their research/performing interests, both of which are presently under used. I hope that future conferences will see a change in this situation. 